\title{
The Effect of Organizational Culture and Employee Competence on Organizational Citizenship Behavior (OCB) with Work Motivation as a Mediation Variable (Case Study in Pekalongan District Land Office)
}

\author{
Ida Uliyah and Setyo Riyanto
}

\section{ABSTRACT}

\begin{abstract}
Having skilled employees is not enough to achieve the goals of an organization. What is most important is how to manage qualified employees to demonstrate their performance actively and engage in work and organizations with skills that cover all or even beyond their formal roles and responsibilities. Employees are expected by the organization, not in terms of completing tasks that conform to usual behavior but also behavior that provides performance that exceeds expectations or extra-role behavior. This extra-role behavior is also known as OCB. In this study, three variables can affect OCB, namely organizational culture, employee competence, and motivation as mediating variables. In measuring the relationship between the third variable and OCB, the researcher uses the SmartPLS application. And the results of the study show that organizational culture has a positive and significant effect on $\mathrm{OCB}$, employee competence has a positive and significant effect on $\mathrm{OCB}$, motivation can mediate the effect of employee competence on $\mathrm{OCB}$ but work motivation cannot judge the relationship between organizational culture and $\mathrm{OCB}$.
\end{abstract}

Keywords: Employee Competence, OCB, Organizational Culture, Work Motivation.

\author{
Submitted : July 30, 2021 \\ Published : September 12, 2021 \\ ISSN: $2507-1076$ \\ DOI: $10.24018 / \mathrm{ejbmr} .2021 .6 .5 .1010$ \\ Ida Uliyah* \\ University of Mercu Buana, Jakarta \\ Indonesia. \\ (e-mail: idauliyah@gmail.com) \\ Setyo Ariyanto \\ University of Mercu Buana, Jakarta, \\ Indonesia. \\ (e-mail: setyo.riyanto@mercubuana.ac.id)
}

*Corresponding Author

\section{INTRODUCTION}

An organization with skilled employees is not enough to achieve the goals of the organization. The most important thing is how to manage these qualified employees so that they show their performance actively and are involved in all jobs and organizations with the expertise they have or even exceed their formal roles and responsibilities. The quality of human resources in the company can be seen from how many employees can contribute and complete all their tasks well. However, it can be seen how many employees have the initiative in completing other work outside of the job description. The behavior of employees expected by the organization is in completing tasks by their usual duties (in the role) and employees who are willing to provide performance that exceeds expectations or extra-role behavior. This extra-role behavior is also known as OCB.

The Land Office is a public organization authorized to administer land management and provide services to the community in the land sector. The Land Office of Pekalongan Regency is located at Jalan Wiroto Number 17 A Wiradesa Pekalongan. The Pekalongan Regency Land Office employees, as of December 31, 2020, are 32 people consisting of 7 structural officials, 14 certain functional officials, and 11 staff. The Assisted by 53 PPNPN employees, 11 licensed cadastral surveyor assistants (ASKB), three mapping officers, and 11 support teams.

Based on the results of interviews with the Head of Personnel Affairs or the planning and control section of human resources regarding OCB behavior in employees, it can be concluded that the level of OCB behavior in Pekalongan Regency Land Office employees is not high enough because employees tend to focus on achieving work targets. In contrast, OCB is significant for an organization, especially during the current pandemic where office policy conditions need to be readjusted. Employees are often found to complain, lack enthusiasm, and do not care about the work environment in the office environment. Of course, such employees cannot support the organization effectively and efficiently. On the other hand, several employees have positive behavior. This then becomes a particular concern because one of the advantages of an organization is the Reliability of its human resources. OCB is considered necessary in the office environment, especially the service sector, where this will affect the quality of services provided to the broader community.

Apart from interviews to strengthen the research, the author conducted a pre-survey to find out the actual OCB behavior that occurred in employees using a questionnaire about OCB, which was distributed to 30 respondents, namely employees of the Pekalongan Regency Land Office. Based on the pre-survey results regarding $\mathrm{OCB}$, the average value 
obtained from each statement is in the range of number 3 from the maximum value of 5. The lowest average value is found in the statement, "I dare to take any risk to be responsible and implement the results joint meeting," with an average score of 3.70 and the highest average score in the statement "I will complete every task given by me with full responsibility" with an average score of 4.33 . So, it can be concluded that employees do not always want to be in a quite risky situation even though the goal is for the benefit of the organization; this is related to the OCB indicator, namely "Conscientiousness." Voluntary behavior is not an employee's obligation or duty. This indicator reaches far above and beyond the call of duty. On the other hand, employees feel pretty responsible for the tasks that are their obligations, not only doing the bare minimum but this work is done as well as possible because employees feel fully accountable for the results of their work. In addition, we can see the statement, where the value obtained is relatively low, so we can conclude that some employees have complained about the company's tasks and policies.

Based on the data from the pre-survey of the OCB behavior questionnaire, it can be said that OCB behavior in the Land Office of Pekalongan Regency is still not high because it only shows an average value of 3.90 below the target figure of 4.50 .

Several factors can influence OCB that occurs in employees. After getting the results from the survey, the authors then conduct a follow-up survey to find out what factors can affect OCB according to employees of the Pekalongan Regency Land Office. From the survey results, it was found that the highest marks were on the motivational factor. Employees believe that OCB behavior can arise when someone has high motivation at work. Jennifer and Jones suggest that employees who have good behavior, are willing to try and work hard, and do not give up easily are characteristics of OCB behavior [1], [2]. High work motivation significantly affects the emergence of OCB behavior in the organization. Research conducted by Danendra \& Mujiati states that reason has a positive and significant effect on OCB [3].

Employees who work with high motivation will produce good work results, which will then encourage OCB behavior. In the second and third ranks, there are organizational culture and employee competencies. OCB is a form of voluntary activity of executive members that supports managerial functions. This behavior is more altruistic (helping), which is expressed in the form of actions that show selflessness and concern for the welfare of others. Organizational culture is a system of beliefs and values that develop within the organization and direct the behavior of its members. No two individuals are alike; no organizational culture is identical. Experts and consultants believe that cultural differences significantly influence corporate performance and the quality of work-life experienced by executive members [4]. Thus, organizational culture has a direct influence on OCB [4].

Then the last is the competency factor, which is another critical factor that needs to be considered if the organization wants its employees to behave OCB. Sutrisno states that competence is an ability based on skills and knowledge supported by work attitudes and refers to the work requirements set [5]. The problem that exists at the
Pekalongan Regency Land Office related to competence is the compatibility between educational background and existing job desks and the provision of employee training that has not been evenly distributed. The three factors are undoubtedly interrelated in the formation of OCB behavior.

The result of the pre-survey overall average mark of work motivation in the Land Office of Pekalongan Regency is 3.99, slightly above the results of the OCB pre-survey. The lowest score is on the statement "I always get feedback from the work I have done," where it only gets a score of 3.56. It can be concluded that employees are not motivated enough because there is no good feedback on what has been done. At the same time, the input itself can have many functions, including increasing success, correcting mistakes, helping to uncover misunderstandings, suggesting specific improvements, providing suggestions for improvement for the future, praising or even punishing. All of these benefits are, of course, in varying degrees of effectiveness according to conditions. Both positive and negative feedback can have a positive effect on learning. While the highest score is in the statement "I always have the passion for making clear targets to complete the work," it means that employees have motivation by setting targets for their work to be completed on time with good results. Regardless of the type of work, it is essential to set goals. To achieve success and ensure that you always feel motivated and committed to completing what you are responsible for. That is why the targets that are made must be as realistic as possible.

The pre-survey results of organizational culture showed the same results with work motivation, which was 3.99. The lowest score is at the statement "I feel that the organization gives freedom to do work in my own way" with a value of 3.26. This result shows that employees feel they are not free enough to do their work. Whereas in terms of doing work, freedom is essential. Employees are given space, but not liberty without limits but freedom with responsibility. The freedom given is also one of the organization's efforts to allow employees to express and be creative. While the highest result is in the statement "I always maintain the quality of work well" with a value of 4.46 , this result shows that employees always maintain the quality of their work well.

The results of the pre-survey of employee competency variables are on average 3.78. This figure is still considered relatively low. The lowest value is in a statement, namely "I have sufficient knowledge about the job desc" this shows that some employees still feel they do not have sufficient knowledge of their job desc. The preparation of this job description is essential, especially to avoid differences in understanding to avoid duplicate work and know the limits of responsibility and authority of each position. While the highest score is in a statement, namely "I believe a good attitude to co-workers will support in completing work that requires teamwork," this shows good cooperation between co-workers in the team.

Based on the results of surveys, interviews, and previous research, the authors decided to take the research title "The Influence of Organizational Culture and Employee Competence on Organizational Citizenship Behavior (OCB) With Work Motivation as a Mediation Variable" (Case Study at the Pekalongan Regency Land Office). 


\section{LITERATURE REVIEW}

\section{A. Organizational Culture}

According to Robbins and Judge, the definition of organizational culture is as follows: "Organizational culture refers to a system of shared meaning held by members that distinguish the organization from other organizations." The above definition can be interpreted that organizational culture is a shared meaning held by members that distinguish the organization from other organizations [6]-[8]. Three forces play an essential role in maintaining a culture, namely selection practices, management actions, and methods of socialization [9].

According to Robbins and Judge the elements of corporate culture above can be interpreted as follows [10], [11]:

1. Innovation and risk-taking;

2. Attention to detail;

3. Outcome orientation;

4. People orientation;

5. Team orientation;

6. Aggressiveness;

7. Stability.

\section{B. Employee Competency}

Competence is a combination of knowledge, skills, values, and attitudes that are reflected in the habits of thinking and acting [12]-[14].

According to Gordon explains several aspects contained in the dimensions of competence are as follows [2], [5], [15]:

1. Knowledge;

2. Understanding;

3. Ability / Skill;

4. Value;

5. Attitude Feelings (happy-not happy, like-dislike);

6. Interest.

\section{Work Motivation}

Work motivation is defined as a condition that is a set of attitudes and values that influence individuals to work [6], [13], [16], [17].

The indicators of work motivation are as follows:

1. Responsibilities and carry out tasks.

2. Carry out tasks with clear targets.

3. Have clear and challenging goals.

4. There is feedback on the results of his work.

5. Have a sense of pleasure at work.

6. Achievement is prioritized from what he does.

\section{Organizational Citizenship Behavior (OCB)}

OCB is constructive behavior but is not included in the employee's formal job description [18], [19]. There are five aspects in OCB mentioned by Organ which, when viewed broadly, can contribute to the work of the organization as a whole, namely [20]-[22]:

1. Altruism;

2. Courtesy;

3. Sportmanship;

4. Civic virtue;

5. Conscientiousness.

\section{FRAMEWORK AND HYPOTHESIS}

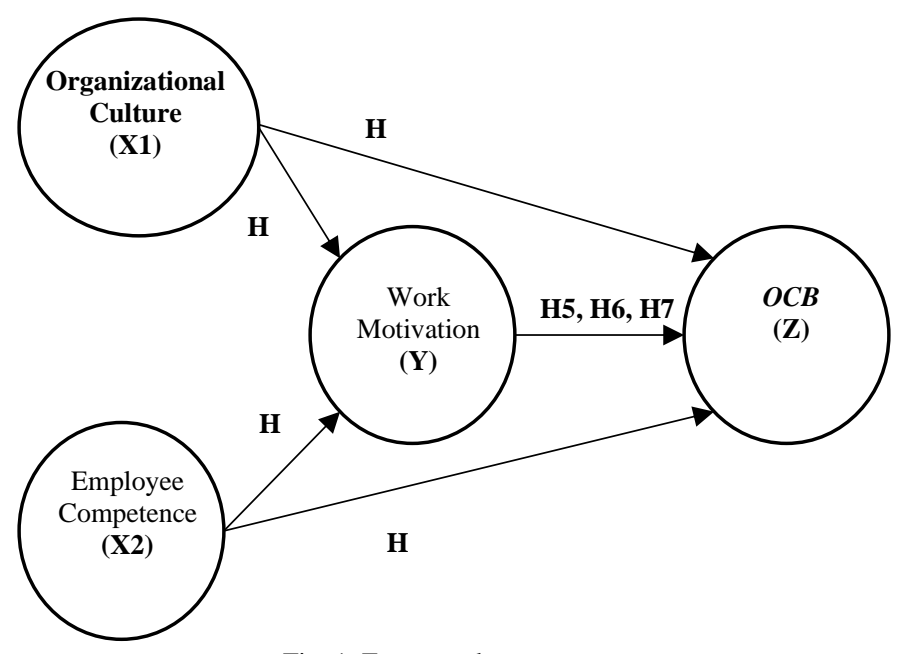

Fig. 1. Framework.

The hypothesis in this study, as follows:

H1: Organizational Culture has a positive and significant effect on Work Motivation.

$\mathrm{H} 2$ : Employee competence has a positive and significant effect on work motivation.

H3: Organizational Culture has a positive and significant effect on OCB.

H4: Employee competence has a positive and significant effect on OCB.

H5: Work Motivation has a positive and significant effect on OCB.

H6: Work motivation mediates the effect of organizational culture on OCB.

H7: Work motivation mediates the effect of employee competence on OCB.

\section{RESEARCH METHODS}

In this study, the author uses the associative method, which is a method that intends to explain the causal relationship and influence between variables through a Hypothesis test.

The data analysis method used in this study is the Component or Variance Based Structural Equation Model, where the data processing uses the Partial Least Square (Smart-PLS) program. The testing steps to be carried out include two stages: evaluation of the outer model or measurement model and assessment of the inner or structural models.

The outer model defines how each indicator block relates to its latent variable. Convergent Validity is the degree to which the measurement results of a concept show a positive correlation with the results of the measurement of other ideas, which theoretically must be positively correlated. Convergent Validity measures the magnitude of the correlation between the construct and the latent variable. Evaluating the Convergent Validity of individual item reliability checks can be seen from the standardized loading factor value. Measurement (indicator) with its construct. The loading factor value above 0.7 can be said to be ideal, meaning that the hand is said to be valid as an indicator that measures the construct. However, the standardized loading factor values above 0.5 are acceptable, while those below 0.5 are excluded from the model [23]-[25]. 
Composite Reliability is done by looking at the view latent variable coefficients. A construct is said to be reliable if the combined reliability value is more than 0.70 . If a construct has met these criteria, it can be noted that the construct is trustworthy or has consistency in the research instrument.

Structural model testing (inner model). Assessing the internal model is to see the relationship between latent constructs by looking at the estimation results of the path parameter coefficients and their level of significance [24], [25]. The estimated value for the path relationship in the structural model must be significant. The bootstrapping procedure can obtain this critical value. Looking at the significance of the hypothesis by looking at the parameter coefficient values and the T-statistical significance value in the bootstrapping report algorithm, the $\mathrm{T}$-statistical significance value must be more than 1.96.

Analyzing the effect of mediation, it is required to see changes in the influence of a direct relationship (direct effects) to an indirect connection (indirect path). There are three categories to analyze the mediating impact according to namely no mediation effects, full mediation effects, and partial mediation effects.

\section{POPULATION AND SAMPLE}

The population in this study were all employees of the Land Office of Pekalongan Regency. The sample is part of the number and characteristics possessed by the people [23]. The sampling technique in this study is the Probability Sampling technique, a sampling technique that provides equal opportunities for each member of the population. This sampling technique uses the type of Proportionate Stratified Random Sampling, a sampling technique when the population has members/elements that are not homogeneous and proportionally stratified who will be the target of the research sample use an error rate of $5 \%$, calculation the sampling of representatives from a particular population developed, the sampling used the Slovin formula.

Calculation of sampling using the Slovin formula as follows:

$$
n=N N \cdot d 2+1
$$

where :

$\mathrm{n}=$ sample size;

$\mathrm{N}=$ Population;

$\mathrm{d}=$ real level or error limit.

In determining the number of samples to be selected, the author uses an error rate of $5 \%$, because in every study it is impossible for the results to be $100 \%$ perfect, the greater the error rate, the smaller the sample size. The total population used is 110 people, with the above calculation then:

$$
n=\frac{110}{110(0.0025)+1}=86.27 \text { rounded up to } 86 \text { respondents }
$$

So, from the members of the population that were taken as samples were 86 respondents.

\section{RESUlTS AND DisCUSSION}

Data analysis was conducted to test the Validity of each indicator and the Reliability of the construct. The validity criteria were measured by convergent Validity, while construct reliability was measured by composite Reliability.

\section{A. Evaluation of Measurement (Outer) Model}

This model specifies the relationship between latent variables and their indicators. Or it can be said that the outer model defines how each hand relates to its latent variable.

\section{1) Validity Test}

A validity test is used to measure the Validity or Validity of a questionnaire. A questionnaire is said to be valid if it can reveal something that the questionnaire will measure. This test is carried out using a measure of convergent Validity in PLS. The concurrent validity value of each indicator can be seen from the loading value. Individual indicators are considered valid if they have a loading value above 0.70 ; however, in the research stage of the scale development stage, loading 0.50 to 0.60 is still acceptable [24], [25].

\begin{tabular}{cccc}
\multicolumn{3}{c}{ TABLE I: RESULT FOR CROSS LOADING AFTER CUTTING } \\
\hline \hline Variable & Indicator & $\begin{array}{c}\text { Outer } \\
\text { loading }\end{array}$ & Description \\
\hline Xrganizational & x1.2 & 0,661 & Valid \\
Culture & x1.4 & 0,695 & Valid \\
& x1.5 & 0,876 & Valid \\
Employee & x2.2 & 0,663 & Valid \\
Competence & x2.3 & 0,758 & Valid \\
& x2.4 & 0,713 & Valid \\
& x2.5 & 0,779 & Valid \\
& y1.1 & 0,601 & Valid \\
& y1.2 & 0,859 & Valid \\
Work Motivation & y1.3 & 0,852 & Valid \\
& y1.5 & 0,601 & Valid \\
& y2.2 & 0,681 & Valid \\
Organizational & y2.3 & 0,815 & Valid \\
Citizenship & y2.4 & 0,642 & Valid \\
Behavior & y2.5 & 0,781 & Valid \\
& y2.6 & 0,694 & Valid \\
\hline \hline
\end{tabular}

From Table I, it can be seen that these conditions have been met so that all the constructs in the estimated model meet the criteria of good discriminant validity, meaning that the results of data analysis can be accepted because the values that describe the relationship between constructs develop.

\section{2) Reliability Test}

Measurement of Reliability by using 2 (two) ways, namely:

a. Composite Reliability, if the composite reliability value between constructs and their indicators gives good results above 0.70 . where the results of a loading factor of 0.70 and above are good.

TABLE II: COMPOSITE RELIABILITY

\begin{tabular}{cc}
\hline \hline Variable & Composite reliability value \\
\hline Organizational Culture & 0,803 \\
Employee Competence & 0,819 \\
Work Motivation & 0,846 \\
OCB & 0,875 \\
\hline \hline
\end{tabular}


It can be seen here that the value for all variables has a composite reliability value of $>0.5$, meaning that it has a good reliability value and can be used for different research processes. What is meant by reliable here is that the indicators used in fundamental research are by the actual conditions of the research object.

b. Apart from composite Reliability, to assess the Reliability of a construct, it can also be done by looking at the Average Variance Extracted (AVE). If the AVE value is > 0.5 , then the indicators used in research are reliable and can be used for analysis.

\begin{tabular}{ccc}
\multicolumn{3}{c}{ TABLE III: AVE } \\
\hline \hline Variable & AVE & AVE root \\
\hline Organizational Culture & 0,51 & 0.714 \\
Employee Competence & 0,531 & 0.728 \\
Work Motivation & 0,53 & 0.728 \\
OCB & 0,587 & 0.766 \\
\hline \hline
\end{tabular}

Table III shows the results of the Average Variance Extracted (AVE) of each construct is good, which is above 0.5 . It can be seen here that the value for Average Variance Extracted and the AVE root obtained has a value $>0.5$; from the results above, all variables have an Average Variance Extracted value $>0.5$, meaning that it has a good reliability value and can be used for different research processes.

\section{B. Structural Model Testing (Inner Model)}

After the estimated model meets the discriminant validity criteria, the structural model test (inner model) is then carried out. Assessing the internal model looks at the relationship between latent constructs by looking at the results of the estimated path parameter coefficients and their level of significance. Here is the Adjusted R-square value on the construct.

TABLE IV: Adjusted R-Square

\begin{tabular}{cc}
\hline \hline Variable & Adjusted R-square \\
\hline Work Motivation & 0,519 \\
OCB & 0,783 \\
\hline \hline
\end{tabular}

Table IV shows that the Adjusted R-square value of the Work Motivation construct (Y1) is 0.519. This means that the Organizational Culture and Employee Competence variables can explain the construct of the Work Motivation variable by $51.9 \%$, while the remaining $(100 \%-51.9 \%=48.1 \%)$ is explained by other variables.

The adjusted R-square construct of Organizational Citizenship Behavior (Y2) is 0.783. This means that the variable constructs of Organizational Culture, Employee Competence, and Work Motivation are able to explain the variable construct of Organizational Citizenship Behavior (Y2) of $78.3 \%$, while the remaining $(100 \%-78.3 \%=21.7 \%)$ is explained by another variable.

\section{Research Model}

The results of data processing using PLS software tools, the output results of the loading factor construct structure model will be obtained to explain the relationship between the constructs shown in Fig. 2.

To determine whether a hypothesis is accepted or not by comparing $\mathrm{t}$-count with $\mathrm{t}$-table provided that if $\mathrm{t}$-count $>\mathrm{t}$ table or $\mathrm{p}$ values < alpha level $(0.05)$, then the hypothesis is accepted. For more details can be seen in Table V below.

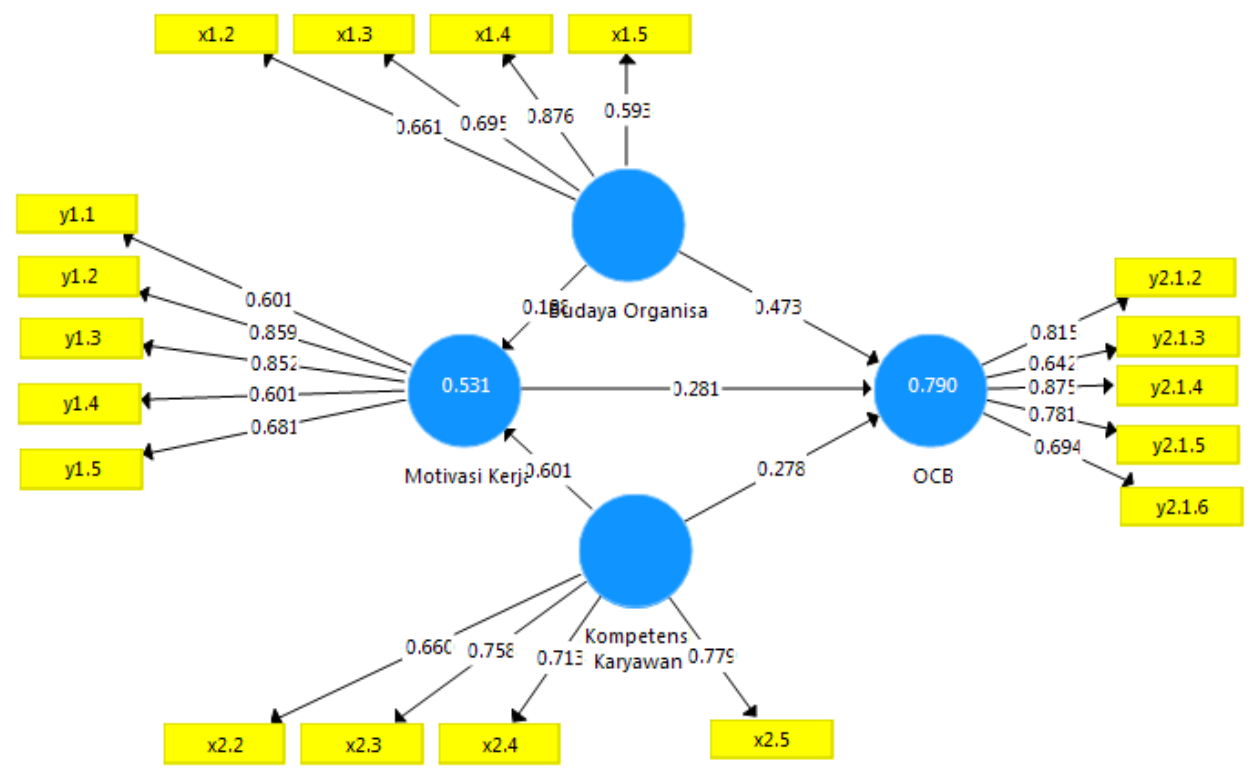

Fig. 2. Algorithm Results Display.

TABLE V: HYPOTHESIS TESTING

\begin{tabular}{|c|c|c|c|c|c|}
\hline Variable & $\begin{array}{l}\text { Original } \\
\text { Sample }\end{array}$ & $\begin{array}{l}\text { Average Sampel } \\
\text { (M) }\end{array}$ & $\begin{array}{l}\text { Standar Deviasi } \\
\quad(\text { STDEV) }\end{array}$ & $\begin{array}{c}\text { T Statistik } \\
(|\mathrm{O} / \mathrm{STDEV}|)\end{array}$ & P-Values \\
\hline Organizational Culture -> Work Motivation & 0,188 & 0,197 & 0,093 & 2,025 & 0,043 \\
\hline Organizational Culture $->$ OCB & 0,473 & 0,479 & 0,075 & 6,288 & 0 \\
\hline Employee Competence -> Work Motivation & 0,601 & 0,598 & 0,091 & 6,586 & 0 \\
\hline
\end{tabular}


Based on the PLS test in Table V above against the first hypothesis, namely the influence of organizational culture (x1) on work motivation (y1), it is known that the original sample estimate result is 0.188 , the $\mathrm{t}$ value $(2.025)>\mathrm{t}$ table (2.00) and the P-value $0.043<0.05$. Organizational culture has a significant positive effect on work motivation, meaning that the better the organizational culture, the higher the work motivation, thus $\mathrm{H} 1$ is accepted.

Based on the results of the PLS test in Table V above against the second hypothesis, namely the effect of Employee Competence (x2) on Work Motivation (y2), it is known that the original sample estimate result is 0.601 , the $t$ value (6.586) $>\mathrm{t}$ table (2.00) and the P-value values $0.000<0.05$. Employee competence has a significant effect on work motivation, meaning that the better the employee's competence, the better the employee's motivation. Therefore, $\mathrm{H} 2$ is accepted.

Based on the results of the PLS test in Table V above, Organizational Culture (x1) on Organization Citizenship Behavior (y2), the third hypothesis is known. The original sample estimate result is 0.473 , the $\mathrm{t}$-count value is $6.288>\mathrm{t}$ table (2.00) and the p-value is $0.000<0,05$. There is a significant and positive influence of organizational culture on organizational citizenship behavior, meaning that the better the organizational culture, the higher the organizational citizenship behavior, so H3 is accepted.

Based on Table V above, Employee Competence (x2) on organization citizenship behavior (y2), the fourth hypothesis is known that the original sample of estimate value is 0.278 , the $\mathrm{t}$-count value is $3.206>$ the statistical t-value (2.00), and the p-value is $0.001<0.05$ so that it can be concluded that there is a significant and positive influence between employee competence on organizational citizenship behavior, meaning that the better the employee's competence, the higher the organizational citizenship behavior, so $\mathrm{H} 4$ is accepted.

Based on Table V above, Work Motivation (y1) on Organization Citizenship Behavior (y2), the fifth hypothesis is known that the original sample of estimate value is 0.281 , the $\mathrm{t}$-count value is $3.675>$ the statistical t-value (2.00), and the p-value is $0.000<0.05$ so that it can be concluded that there is a significant and positive influence between work motivation and organizational citizenship behavior, meaning that the better work motivation, the higher organizational citizenship behavior, so $\mathrm{H} 4$ is accepted.

TABLE VI: DIRECT AND INDIRECT INFLUENCE

\begin{tabular}{cccccc}
\hline \hline Variable & $\begin{array}{c}\text { Original } \\
\text { Sample } \\
(\mathrm{O})\end{array}$ & $\begin{array}{c}\text { Average } \\
\text { Sampel } \\
(\mathrm{M})\end{array}$ & $\begin{array}{c}\text { Standar } \\
\text { Deviasi } \\
(\text { STDEV })\end{array}$ & $\begin{array}{c}\text { T Statistik } \\
(\mid \mathrm{O} / \mathrm{STDEV})\end{array}$ & $\begin{array}{c}\mathrm{P} \\
\text { Values }\end{array}$ \\
\hline $\begin{array}{l}\text { Organizational Culture }> \\
\begin{array}{l}\text { Work Motivation -> OCB } \\
\text { Employee Competence -> } \\
\text { Work Motivation -> OCB }\end{array}\end{array}$ & 0,053 & 0,053 & 0,029 & 1,841 & 0,066 \\
\hline \hline
\end{tabular}

From Table VI, it can be seen that Organizational Culture has a direct effect on organizational citizenship behavior, this sixth hypothesis is evidenced by the original sample of estimate value of 0.473 which is greater than the original sample of the estimate of organizational culture on organizational citizenship behavior through work motivation of 0.053 in Table VI the relationship between cultural variables organizational citizenship behavior through work motivation as a mediating variable has t-value of $1.841<$ statistical $t$ value (2.00) and a p-value of $0.066>0.05$ so it can be concluded that the work motivation variable cannot mediate the relationship between organizational culture variables on organization citizenship behavior, so Hypothesis 6 is not accepted.

From Table VI, it can be seen that Employee Competence has a direct effect on Organization Citizenship Behavior; this seventh hypothesis is evidenced by the original sample of estimate value of 0.278 , which is greater than the original sample of the estimate of employee competence on organizational citizenship behavior through work motivation of 0.169 in Table VI the relationship between competency variables employees on organizational citizenship behavior through work motivation as a mediating variable has at the value of 3,221 > statistical t value (2.00) and a p-value of $0.001<0.05$ so it can be concluded that work motivation variables can mediate the relationship between employee competence variables on the organizational citizenship behavior, So Hypothesis 7 is accepted.

\section{RESULTS AND DISCUSSION}

\section{A. Conclusion}

1. Organizational Culture has a significant positive effect on Work Motivation, meaning that the better the organizational culture in the Land Office of Pekalongan Regency, the better the work motivation of its employees.

2. Employee competence has a significant effect on work motivation, meaning that the better the employee's competence, the more motivated the employees of the Pekalongan Regency Land Office.

3. Organizational Culture has a significant positive effect on OCB, meaning that the better the organizational culture at the Land Office of Pekalongan Regency, the better the organizational citizenship behavior of its employees.

4. Employee competence has a significant and positive effect on organizational citizenship behavior, meaning that the better employee competence, the better organizational citizenship behavior in the Pekalongan Regency Land Office.

5. Work motivation has a significant positive effect on organizational citizenship behavior, meaning that the better the employee's work motivation, the better organizational citizenship behavior in the Land Office of Pekalongan Regency.

6. Work motivation cannot mediate the relationship between organizational culture variables and 
organizational citizenship behavior. This could be due to several things, one of which is the strong Organizational Culture in the Land Office of Pekalongan Regency.

7. Work motivation can mediate the relationship between employee competence variables on organizational citizenship behavior. This means that when the competence of employees at the land office of Pekalongan Regency is in good condition, it will increase the work motivation of its employees so that it can affect the OCB behavior of its employees.

\section{B. Suggestions}

1. Employees don't just want to work according to directions like robots. They also want to develop with freedom of thought and opinion. This is what the HR department of the Pekalongan Regency Land Office should understand in making policies. Providing space for creativity is an important part of the employee empowerment strategy. Management can make employees directly involved with work, such as identifying problems and thinking about strategies for solving them. This method is also carried out as a form of appreciation for the company's ideas and thoughts that each employee has.

2. To be able to improve employee understanding related to work, the company can conduct training programs or training. Providing training programs for employees will help improve employee skills. The training program will be prepared by the HR department and must be right on target and in accordance with valid data. Guidance on valid data will be able to produce optimal output. The HR department analyzes what sector development is needed. The analysis will refer to the recorded performance of all employees. The training program provided will be able to improve employee skills according to what the organization needs. This training is provided for both ASN and NonASN so that the competence of employees at the Land Office of Pekalongan Regency is evenly distributed.

3. The Land Office of Pekalongan Regency can also try by holding cross-training. By doing this cross-training, the office costs nothing at all. They need to allow employees to brainstorm and teach one another. So that when an employee in that section is unable to attend, the work can be handled by other employees; this is also a goal to improve OCB behavior in the Pekalongan Regency Land Office.

4. Giving appreciation to employees, anyone who is given appreciation from a person or institution will certainly feel happy, including employees who have worked hard. Employees who are happy to be given effort or appreciation will certainly work better. Appreciation is one of the steps for an organization to thank its employees. The appreciation was given also varies, not always in the form of money - for example, iconic small gifts, holiday tickets, additional incentives, and others. Appreciation is deliberately done so that the psychological condition of employees remains in good condition. Good feedback is also an appreciation to employees. In addition to appreciation, another way is to celebrate employee success, for example, achieving work targets. No matter how much achievement an employee has achieved, the organization must be able to give appreciation by celebrating its success. Celebrating success can help increase employee confidence and enthusiasm for work. Employees who have not achieved the targets as desired by the organization will also be motivated and more enthusiastic in their work.

5. In implementing the new policy at the Land Office of Pekalongan Regency, the HR Department can apply several ways so that the new policy can be accepted by employees: Provide appropriate information to all employees on a regular basis, especially those related to targets/goals (goals/objectives) and management policies/decisions. Apply the principle of transparency. In this way, employees will become accustomed to dealing with organizational plans and changes that occur. Without information gaps, change is smooth. Make changes gradually, not immediately. The socialization is carried out in stages to create a new work culture so as to minimize rejection. Get used to employees always being in a position to be given, and their performance monitored. Every year increase the target and its monitoring (evaluation). This way, employees get used to changing all the time and don't get stuck in a comfort zone.

6. Researchers suggest that further research should add other variables that are not in this study, considering that the Organizational Culture and Employee Competence variables can explain the construct of the Work Motivation variable by $51.9 \%$, while the rest is $(100 \%-51.9 \%=48.1 \%)$ is explained by other variables. And the variables of Organizational Culture, Employee Competence, and Work Motivation were able to explain the variable construct of Organizational Citizenship Behavior (Y2) by $78.3 \%$, while the remaining $(100 \%-78.3 \%=21.7 \%)$ was explained by other variables.

7. Researchers suggest that further research can continue research related to work motivation variables as mediation because, in this study, work motivation variables cannot mediate the relationship between organizational culture and OCB.

\section{REFERENCES}

[1] I. Pratiwi, "Analisis Pengaruh Budaya Organisasi dan Keadilan Organisasi Terhadap Organizational Citizenship Behavior (OCB) dengan Komitmen Organisasional Sebagai Variabel Intervening (Studi pada Karyawan Kantor PT Telekomunikasi Indonesia TBK. Divisi Regional IV Wi,” pp. 1-187, 2013.

[2] I. P. Satya Nugraha and I. G. Ayu Dewi Adnyani, "Budaya Organisasi, Komitmen Organaisasi, Dan Kompetensi Terhadap Organizational Citizenship Behaviour Pada Setda Kota Denpasar," EJurnal Manaj. Univ. Udayana, vol. 7, no. 1, p. 1, 2017, doi: 10.24843/ejmunud.2018.v7.i01.p01.

[3] A. Danendra and N. Mujiati, "Pengaruh Motivasi, Kompensasi Dan Komitmen Organisasional Terhadap Organizational Citizenship Behavior (Ocb)," E-Jurnal Manaj. Univ. Udayana, vol. 5, no. 10, p. 255075, 2016

[4] R. P. Setyaningrum, "Relationship between servant leadership in organizational culture, organizational commitment, organizational citizenship behaviour and customer satisfaction," Eur. Res. Stud. J., vol. 20, no. 3, pp. 554-569, 2017. 
[5] A. Anjani, "Pengaruh Kompetensi dan Motivasi Kerja Terhadap Kinerja Karyawan," J. Inspirasi Bisnis dan Manaj., vol. 3, no. 1, p. 1, 2019, doi: 10.33603/jibm.v3i1.2191.

[6] Y. Yovina Vanesa, R. Matondang, I. Sadalia, M. Toyib Daulay, and C. Author, "45 The Influence Of Organizational Culture, Work Environment And Work Motivation On Employee Discipline In PT Jasa Marga (Persero) TBK, Medan Branch, North Sumatra, Indonesia," Am. Int. J. Bus. Manag. ISSN, vol. 2, no. 5, p. 37, 2019, [Online]. Available: www.aijbm.com.

[7] M. Paais and J. R. Pattiruhu, "Effect of Motivation, Leadership, and Organizational Culture on Satisfaction and Employee Performance," J. Asian Financ. Econ. Bus., vol. 7, no. 8, pp. 577-588, 2020, doi: 10.13106/JAFEB.2020.VOL7.NO8.577.

[8] S. P. P. Lestari, "Pengaruh Remunerasi, Kompetensi, Dan Motivasi Terhadap Kinerja Karyawan Dengan Budaya Organisasi Sebagai Variabel Moderating Pada Bank Syariah Indonesia Kc Semarang," 2021, [Online]. Available: http://e-repository.perpus.iainsalatiga.ac.id/id/eprint/10860.

[9] T. Hormati, "Pengaruh Budaya Organisasi, Rotasi Pekerjaan Terhadap Motivasi Kerja Dan Kinerja Pegawai," J. EMBA, vol. 4, no. 2, pp. 298 $310,2016$.

[10] L. N. Hutabarat, P. Studi, M. Manajemen, U. Muhammadiyah, and S. Utara, "Pengaruh Pengawasan, Budaya Organisasi dan Remunerasi Terhadap Motivasi Kerja Pegawai keamanan yang bertanggung jawab atas keamanan individu dan keamanan umum sesuai UU tugas , baik dibidang operasional maupun dibidang pembinaan, dimana satuan kerja Bir," vol. 2, no. 2, pp. 200-213, 2019.

[11] S. P. Robbin and T. A. Judge, "Organizational Behavior," p. 876, 2001.

[12] V. Biagioli, C. Prandi, B. Nyatanga, and R. Fida, "The Role of Professional Competency in Influencing Job Satisfaction and Organizational Citizenship Behavior among Palliative Care Nurses," $J$. Hosp. Palliat. Nurs., vol. 20, no. 4, pp. 377-384, 2018, doi: 10.1097/NJH.0000000000000454.

[13] A. Meidita, "Pengaruh Pelatihan dan Kompetensi Terhadap Kepuasan Kerja Melalui Motivasi Kerja," Maneggio J. Ilm. Magister Manaj., vol. 2, no. 2, pp. 226-237, 2019, doi: 10.30596/maneggio.v2i2.3772.

[14] D. A. Cahya, "Karyawan Dengan Motivasi Kerja Sebagai Variabel Intervening (Studi Kasus Pada Bank BNI Syariah KC Semarang) SKRIPSI," 2019.

[15] E. K. Ningsih, "Pengaruh Komitmen , Kompetensi , Dan Budaya Organisasi Pegawai Puskesmas Bromo Medan Endang Kurnia Ningsih Universitas Islam Sumatera Utara," vol. 1, no. 5, pp. 75-88, 2020.

[16] S. ; W. Nurnaningsih, "Pengaruh Kepuasan Kerja, Motivasi Kerja Dan Komitmen Organisasi Terhadap Kinerja Melalui Organizational Citizenship Behavior (Ocb) Sebagai Variabel Intervening," Econ. Educ. Anal. J., vol. 6, no. 2, pp. 365-378, 2017.

[17] Y. Dharma, "The effect of work motivation on the employee performance with organization citizenship behavior as intervening variable at bank aceh syariah," Emerald Reach Proc. Ser., vol. 1, pp 7-12, 2018, doi: 10.1108/978-1-78756-793-1-00065.

[18] S. Pohl, A. Battistelli, and J. Librecht, "The impact of perceived organizational support and job characteristics on nurses' organizational citizenship behaviours," Int. J. Organ. Theory Behav., vol. 16, no. 2 , pp. 193-207, 2013, doi: 10.1108/IJOTB-16-02-2013-B002.

[19] M. A. Khan, F. B. Ismail, A. Hussain, and B. Alghazali, "The Interplay of Leadership Styles, Innovative Work Behavior, Organizational Culture, and Organizational Citizenship Behavior," SAGE Open, vol. 10, no. 1, 2020, doi: 10.1177/2158244019898264.

[20] A. S. Adianita, S. Mujanah, and C. Candraningrat, "Kompetensi Karyawan, Emotional Quotient Dan Self Efficacy Pengaruhnya Terhadap Organizational Citizenship Behavior Dan Kinerja Karyawan Pada Indomobil Grup Di Surabaya," J. Ris. Ekon. dan Manaj., vol. 17, no. 1, p. 199, 2017, doi: 10.17970/jrem.17.170114.id.

[21] A.; F. M. Kinicki, "( PDF ) Organizational Behavior: Key Angelo Kinicki, Mel Fugate - download pdf free Description :"

[22] Musringudin, M. Akbar, and N. Karnati, "The Effect of Organizational Justice, Job Satisfaction, and Organizational Commitment on Organizational Citizenship Behavior (OCB) of the Principles," Indones. J. Educ. Rev., vol. 4, no. 2, pp. 155-165, 2017.

[23] A. Purwanto, M. Asbari, and T. I. Santoso, "Analisis Data Penelitian Marketing: Perbandingan Hasil antara Amos, SmartPLS, WarpPLS, dan SPSS untuk Jumlah Sampel Besar," J. Ind. Eng. Manag. Res., vol. 2, no. 4, pp. 216-227, 2021, [Online]. Available https://www.jiemar.org/index.php/jiemar/article/view/178/138.

[24] T. Sander and T. P. Lee, "New Challenges of Economic and Business Development - 2014 Smartpls for the Human Resources Field New Challenges of Economic and Business Development - 2014," 2014.

[25] M. Sarstedt, C. M. Ringle, and J. F. Hair, "Partial Least Squares Structural Equation Modeling," Handb. Mark. Res., no. July, pp. 1-47, 2021, doi: 10.1007/978-3-319-05542-8_15-2. 